\title{
Characterization by GC-MS of the Main Ethanolic Extract'S Components from the Bark of Talipariti elatum Sw. (Fryxell) Malvaceae
}

\author{
José González (Correspondence author) \\ Department of Pharmacy, Faculty of Pharmacy and Foods, Havana University, Cuba
}

Tel: 53-7262-6664 E-mail: jgyaque@ifal.uh.cu

Armando Cuéllar

Department of Pharmacy, Faculty of Pharmacy and Foods, Havana University, Cuba

\section{Enrique Gómez}

Department of Pharmacy, Faculty of Pharmacy and Foods, Havana University, Cuba

\author{
Julio Pérez
}

National Center of Toxicology (CENATOX), Military Hospital "Carlos J. Finlay", Cuba

\section{Max Monan}

ARVARNAM, 16 lot. les Rosiers, Quartier Thoraille, 97215, Rivière-Salée, Martinica

Received: December 15, 2017 Accepted: March 4, 2018 Published: March 7, 2018

Doi: 10.5296/jab.v6i2.12784 URL: http://doi.org/10.5296/jab.v6i2.12784

\begin{abstract}
Talipariti elatum (Sw.), commonly named Blue Mahoe, is used as antasthmatic, antitussive, against catarrh and expectorant in phytotherapy in Cuba, although the plants' composition has not been determined in detail so far. An ethanolic extract from the bark of Talipariti elatum Sw. (Fryxell) Malvaceae that grows in Cuba was prepared by Soxhlet extraction with ethanol
\end{abstract}


at $95 \%$ during 20 hours. The crude extract without purification was analyzed using a GCMS-QP2010 Ultra Shimadzu, and the components were identified by comparing their retention times and their mass spectra with those of NIST21Library. About 45 different chemical compounds were detected in the sample and from them, 31 chemical components were characterized and reported for the first time from Talipariti elatum. Our results demonstrate the developed method could be employed as a rapid and versatile analytical technique for identification of chemical constituents and quality control of Talipariti samples.

Keywords: Talipariti, Bark, GC-MS, Ethanolic extract, Chemical composition

\section{Introduction}

Today search of natural bioactive substances with antioxidant, antimicrobial, antiinflammatory properties and other therapeutic effects is developing rapidly, because of the growing interest of consumers for this kind of products, and willingness of policy makers to validate and enhance the natural heritage and ancestral knowledge.

Talipariti elatum tree is quite attractive with its straight trunk, broad green leaves and hibiscus-like flowers. It grows quite rapidly, often attaining 20 meters $(66 \mathrm{ft})$ or more in height. The attractive flower changes color as it matures, going from bright yellow to orange red and finally to crimson. The name mahoe is derived from a Carib word. The 'blue' refers to blue-green streaks in the polished wood, giving it a distinctive appearance (U.S. Department of Agriculture, 2013).

Talipariti elatum is native to the islands of Cuba, Jamaica, US. Virgin Islands, Puerto Rico and Martinica. In wetter areas it will grow in a wide range of elevations, up to 1,200 meters $(3,900 \mathrm{ft})$ and is often used in reforestation. It is the national tree of Jamaica (Tropicos.org. Missouri Botanical Garden, 2013). The inner bark of the tree is often referred to as Cuba bark because it was formerly used for tying bundles of Havana cigars (Areces \& Fryxell, 2007).

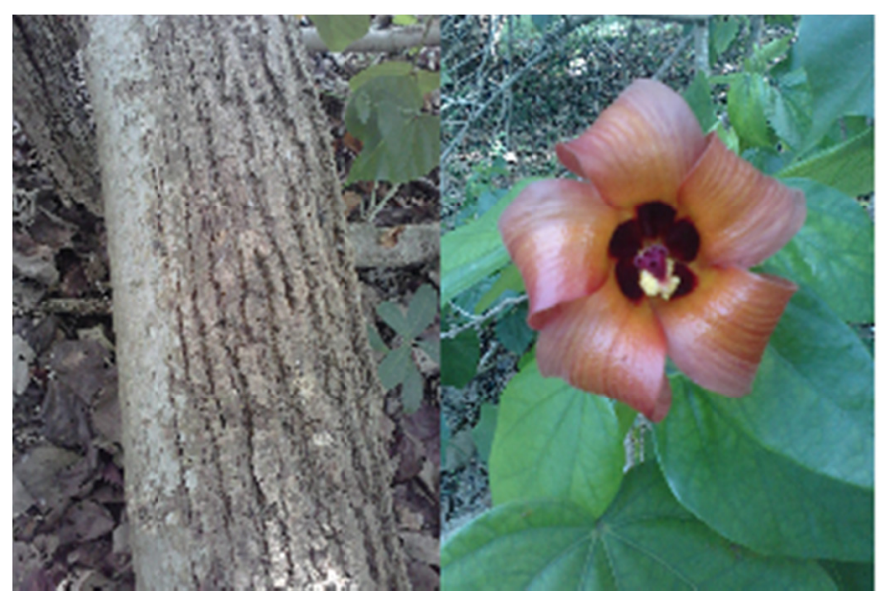

Figure 1. Trunk, leaves and flower of Talipariti elatum Sw. (Fryxell).

The evaluation of macromorphology characteristics possibility to define that bark is grayish in color, $37 \mathrm{~cm}$ long, $15-16 \mathrm{~cm}$ wide and $2.5-4 \mathrm{~cm}$ high, characteristic smell and lightly astringent taste (Figure 2). 


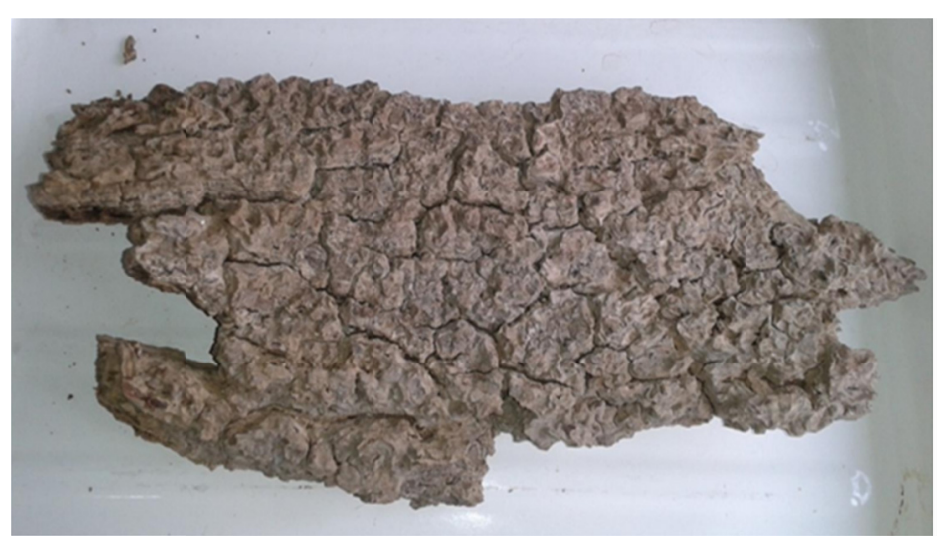

Figure 2. Bark of Talipariti elatum Sw. (Fryxell)

Powdered drug is brown in color and keep its characteristic smell and taste. Micromorphological characteristics of powdered drug show the presence of fibers and serous or chlorenchymatic cells penthagonal or hexagonal in form (Figure 3).

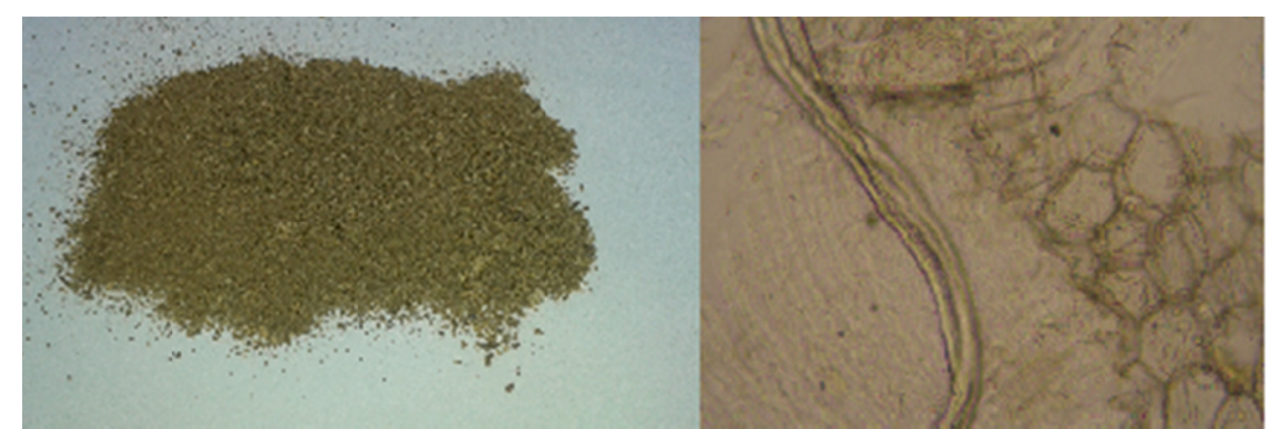

Figure 3. Powdered drug and micromorphological characteristics of the bark

Phytochemical screening from ethanolic extract of the bark testing to detect for the presence of different chemical groups of compounds showed the presence of triterpenes and/or steroids, reductants sugars, phenolic compounds, aminoacids and/or amines, quinones and bitter and/or astringent principles. Oil or fats, alkaloids, flavonoids and anthocyanin were absent (Gómez, 2017; González et al., 2017).

The aim of the present study was to identify the phytocomponents of this plant and subjecting the ethanol extract of the plant's bark to Gas Chromatography-Mass Spectrum analysis.

\section{Materials and Methods}

\subsection{Plant Material}

Bark of the plant was collected in January 2017 in the gardens of the Faculty of Pharmacy and Foods at Havana University, and identified at the herbarium of National Botany Garden of Havana, where the voucher specimen no. HAJB 82587 has been deposited. Specimen is registered as Talipariti elatum Sw. (Fryxell) Malvaceae (Sin. Hibiscus elatus Sw.).

\subsection{Plant Sample Extraction-Soxhlet Extraction Method}

The sample was cleaned twice with distilled water. Then the sample was dry in an oven with 
controlled temperature at $40{ }^{\circ} \mathrm{C}$ during 5 days. After dried, the sample was pulverized to powder using a mechanical grinder. The particles were uniformed using a sieve $(1 \mathrm{~mm})$. The powder was stored in an air-dried packet.

Plant material $(80 \mathrm{~g})$ was extracted successively with $700 \mathrm{~mL}$ of ethanol at $95 \%$ by using a Soxhlet extractor until a complete extract was done (20 hours). The extracts were concentrated under a rotovaporator (Heidolph, Germany) up to $200 \mathrm{~mL}$ at $120 \mathrm{rpm}, 70{ }^{\circ} \mathrm{C}$ and a pressure of 500 mbar. All reagents used were of analytical grade (Merck). All solvents were degassed prior to use in an ultrasonic bath without filtration.

\subsection{HPLC Analysis}

HPLC analysis of ethanolic extract from the bark was registered using an HPLC Knauer-Azura (Germany) equipped with an UV detector at $280 \mathrm{~nm}$. Chromatographic conditions: Flow (1 mL/min); Column (RP-18e Knauer $250 \times 4.6 \mathrm{~mm}$ Lichrospher 100-5); Manual injection (50.00 $\mu \mathrm{L}$, twice); Running time (60 min); Pump pressure (11.7 MPa); Gradient (eluent A: water, eluent B: methanol, 15-85\% B during 30 min, follow by holding, increasing to $50 \%$ A during $10 \mathrm{~min}$, reversing to $0 \% \mathrm{~B}$ during $5 \mathrm{~min}$ and equilibrating during $5 \mathrm{~min}$ ).

\subsection{GC-MS Analysis}

For the identification of metabolites present in the bark the sample were subjected to chromatographic analysis in equipment GC/MS, brand Shimadzu QP2010, equipped with a splitter split/splitless. With a BP5 $(30 \mathrm{~m} \times 0.25 \mathrm{~mm} \times 0.25$ microns $)$ capillary column under the following chromatographic conditions: Helium gas carrier obtained by electron impact fragments to a power of $70 \mathrm{eV}$ rate of $1.2 \mathrm{~mL} / \mathrm{min}, 1: 50$ split flow and the volume of injected sample of $1 \mathrm{ul}$. Programmed oven temperature: initial temperature was $70^{\circ} \mathrm{C}$ with a heating ramp of $10{ }^{\circ} \mathrm{C} / \mathrm{min}$ to $300{ }^{\circ} \mathrm{C}$ and remained stable at this temperature for 10 minutes. Subsequently the temperature was increased at a rate of $10{ }^{\circ} \mathrm{C} /$ minute to $300{ }^{\circ} \mathrm{C}$ for a total time of 78 minutes with an injector temperature $250{ }^{\circ} \mathrm{C}$ and the interface temperature 300 ${ }^{\circ} \mathrm{C}$. The compounds were analyzed using GC/MS NIST21 library and having into account the results obtained after phytochemical screening according with Gómez (2017). Silylation agent was $N, O$-bis (trimethylsilyl) trifluoroacetamide (BSTFA) CAS 25561-30-2 Lot: 0901-1 Macherey-Nagel GmbH \& C. KG.

\subsection{Data Analysis}

Comparison of the spectra with the NIST database using a probability-based matching algorithm was performed to achieve compound identification, along with comparison of relative retention indices (RI) to literature and standard reference values.

\section{Results and Discussion}

\subsection{Chromatographic Profile by HPLC}

In Talipariti elatum 24 peaks in HPLC-UV chromatogram were identified as shown in figure 4. Their retention times were between 1.267 and 46.017 minutes, although the chromatogram resolution is not the most ideal after this retention time and up to 50 minutes, which allow us inferred that there are other components into analyzed sample. The most prominent peaks belongs to compounds 2 (2.083 $\mathrm{min}), 3$ (2.950 $\mathrm{min}), 4(3.450 \mathrm{~min})$ and 24 (46.017 $\mathrm{min})$, giving an idea that they are the majoritarian chemical components in the sample. 
Resolution may be was not better because the sample was injected without dilution, and perhaps this condition had not permitted a better separation of all components present in the sample, although some minoritarian compounds were not registered because their few concentration.

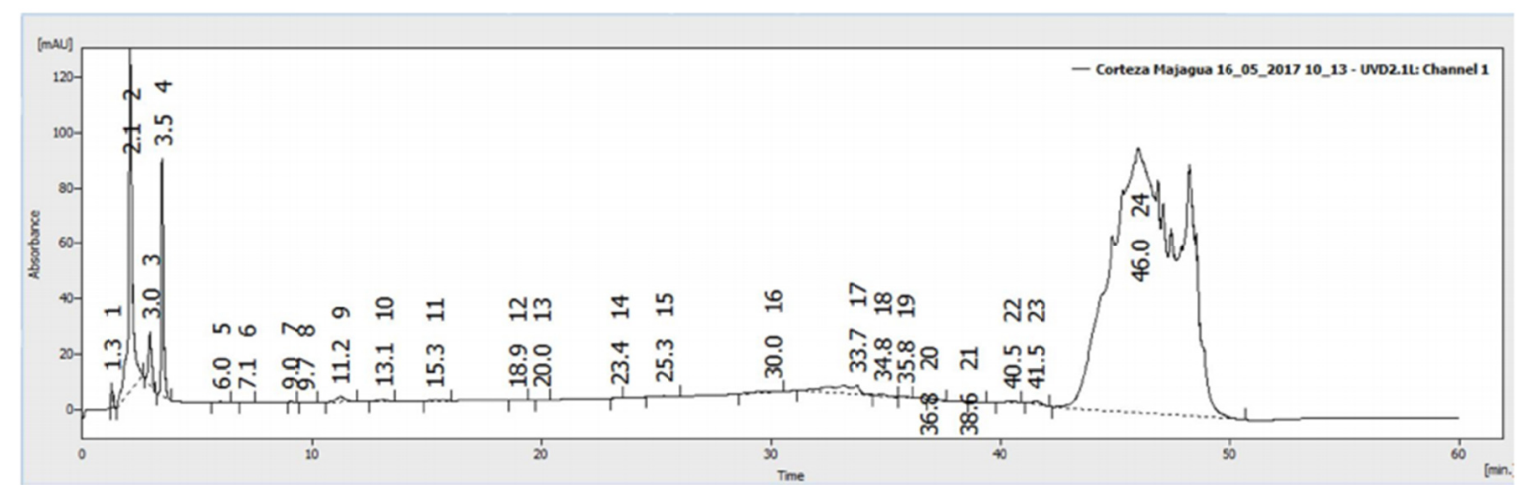

Figure 4. HPLC-UV chromatogram of ethanolic extract of Talipariti elatum at $280 \mathrm{~nm}$

\subsection{Chemical characterization by GC-MS}

GC-MS is one of the most efficient technology platforms to approach complex mixtures of organic compounds based on a combination of MS database search and the use of calculated RI values. Suitable MS and RI resources have been developed and are well established for the analysis of e.g., essential oil constituents (Adams, 2007; Hochmuth, 2014; Skogerson et al., 2011), and investigation of environmental samples using either the comprehensive NIST or Wiley MS libraries or vendor-specific and customized databases.

In the case of silylation-based derivatization techniques which cover a broad range of molecular masses and different polarities, the information base regarding phenolic and other cyclic structures, belonging to the complex group of plant secondary metabolites, is rather limited. This is particularly true for higher molecular weight compounds $(\geq 300)$ as pointed out by Isidorov and Szczepaniak, 2009. However, the specificity of molecular structures and thus MS fragmentation patterns in most cases allow for the assignment of distinct compound groups and sub-classes.

The peaks are marked with retention time in the GC-MS chromatogram of ethanolic extract of the bark from Talipariti elatum. Their retention times $\left(\mathrm{R}_{\mathrm{T}}\right)$ and their corresponding names are listed in Table 1. The qualitative analysis of the ethanolic extract showed the presence of 45 different kind of chemical compounds (Figure 5) and among them, only 31 received the proposal of chemical characterization. Authors have had into account the results of phytochemical screening for the proposal chemical structures according to Gómez in 2017, where the main chemical components in ethanolic extract were triterpenes/steroids, reductants sugars, tannins/phenolic compounds, aminoacids/amines, quinones and bitter or astringent principles. 


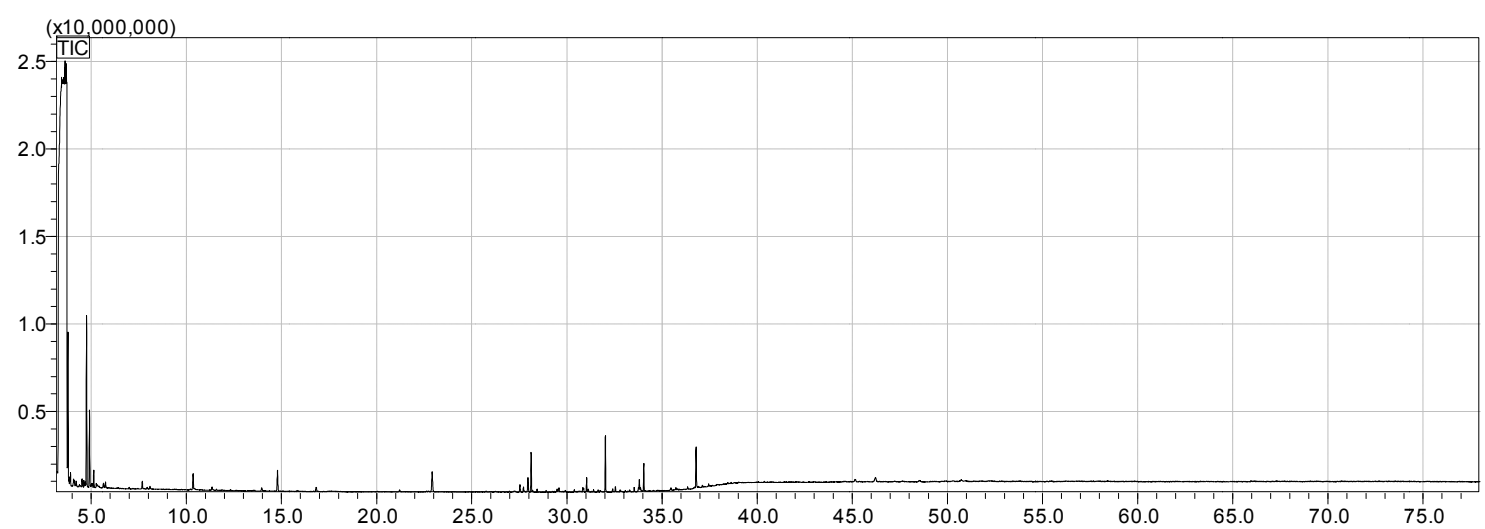

Figure 5. Current chromatogram by GC of ethanolic extract from bark of T. elatum $\mathrm{Sw}$

Table 1. The chemical composition of bark from Talipariti elatum $\mathrm{Sw}$

\begin{tabular}{|c|c|c|c|c|c|c|}
\hline $\begin{array}{l}\text { Peak } \\
\#\end{array}$ & R.Time & $\begin{array}{l}\text { Molecular } \\
\text { formula }\end{array}$ & $\begin{array}{l}\text { Molecular } \\
\text { weight }\end{array}$ & $\begin{array}{l}\text { Base } \\
\text { Peak }\end{array}$ & CAS & $\begin{array}{l}\text { Library ID/ } \\
\text { Compound } \\
\text { Name }\end{array}$ \\
\hline 1 & 3.880 & $\mathrm{C}_{8} \mathrm{H}_{18} \mathrm{O}_{2} \mathrm{Si}$ & 174 & 73.00 & $17728-88-0$ & Propanoic acid \\
\hline 2 & 3.910 & $\mathrm{C}_{9} \mathrm{H}_{20} \mathrm{O}_{3} \mathrm{Si}_{2}$ & 232 & 146.95 & $55191-13-4$ & $\begin{array}{l}\text { 2-propenoic acid } \\
\text { (pyruvic acid) }\end{array}$ \\
\hline 3 & 3.910 & $\mathrm{C}_{8} \mathrm{H}_{18} \mathrm{O}_{4} \mathrm{Si}_{2}$ & 234 & 146.95 & 18294-04-7 & $\begin{array}{l}\text { Ethanedioic acid } \\
\text { (oxalic acid) }\end{array}$ \\
\hline 4 & 5.645 & $\mathrm{C}_{7} \mathrm{H}_{17} \mathrm{NO}_{2} \mathrm{Si}$ & 175 & 58.05 & $0-00-0$ & N,N-Dimethylglycine \\
\hline 5 & 5.645 & $\mathrm{C}_{13} \mathrm{H}_{23} \mathrm{ONOSi}$ & 237 & 58.05 & $54833-35-1$ & Benzanethanamine \\
\hline 6 & 5.645 & $\mathrm{C}_{13} \mathrm{H}_{23} \mathrm{ONOSi}$ & 237 & 58.05 & $0-00-0$ & Ephedrine \\
\hline 7 & 5.645 & $\mathrm{C}_{14} \mathrm{H}_{20} \mathrm{~N}_{2} \mathrm{O}_{2}$ & 248 & 58.05 & $0-00-0$ & 2,3- dihydroindan-2-one \\
\hline 8 & 5.750 & $\mathrm{C}_{8} \mathrm{H}_{11} \mathrm{~N}$ & 121 & 121 & $1462-84-6$ & 2,3,6-trimehyl Pyridine \\
\hline 9 & 7.685 & $\mathrm{C}_{11} \mathrm{H}_{23} \mathrm{O}_{3} \mathrm{Si}_{2}$ & 262 & 73.00 & $55557-17-0$ & $\begin{array}{l}\text { 2-methyl-3-oxy-butanoic } \\
\text { acid }\end{array}$ \\
\hline 10 & 10.350 & $\mathrm{C}_{11} \mathrm{H}_{24} \mathrm{O}_{2} \mathrm{Si}$ & 216 & 73.00 & $0-00-0$ & Octanoic acid \\
\hline 11 & 27.715 & $\mathrm{C}_{13} \mathrm{H}_{32} \mathrm{O}_{4} \mathrm{Si}_{3}$ & 336 & 73.00 & $0-00-0$ & d-Erythrotetrofuranose \\
\hline 12 & 27.715 & $\mathrm{C}_{14} \mathrm{H}_{34} \mathrm{O}_{4} \mathrm{Si}_{3}$ & 350 & 73.00 & $0-00-0$ & 2-deoxyribose \\
\hline 13 & 27.715 & $\mathrm{C}_{17} \mathrm{H}_{24} \mathrm{O}_{5} \mathrm{Si}_{4}$ & 438 & 73.00 & $0-00-0$ & Xylulose \\
\hline 14 & 27.715 & $\mathrm{C}_{16} \mathrm{H}_{42} \mathrm{O}_{4} \mathrm{Si}_{4}$ & 410 & 73.00 & $32381-52-5$ & Threitol \\
\hline 15 & 31.130 & $\mathrm{C}_{24} \mathrm{H}_{62} \mathrm{O}_{6} \mathrm{Si}_{6}$ & 614 & 73.00 & $14317-07-8$ & D-Mannitol \\
\hline 16 & 31.130 & $\mathrm{C}_{24} \mathrm{H}_{62} \mathrm{O}_{6} \mathrm{Si}_{6}$ & 614 & 73.00 & $0-00-0$ & Dulcitiol \\
\hline
\end{tabular}




\begin{tabular}{lllllll}
\hline \hline 17 & 31.130 & $\mathrm{C}_{20} \mathrm{H}_{52} \mathrm{O}_{5} \mathrm{Si}_{5}$ & 512 & 73.00 & $14199-72-5$ & Xylitol \\
18 & 31.130 & $\mathrm{C}_{24} \mathrm{H}_{62} \mathrm{O}_{6} \mathrm{Si}_{6}$ & 614 & 73.00 & $18919-39-6$ & Galactitol \\
19 & 32.025 & $\mathrm{C}_{16} \mathrm{H}_{34} \mathrm{O}_{2} \mathrm{Si}$ & 286 & 116.95 & $169597-14-2$ & Tridecanoic acid \\
20 & 33.755 & $\mathrm{C}_{21} \mathrm{H}_{40} \mathrm{O}_{2} \mathrm{Si}$ & 352 & 67.00 & $56259-07-5$ & $\begin{array}{l}9,12-O c t a d e c a d i e n o i c \\
\text { acid }\end{array}$ \\
21 & 33.755 & $\mathrm{C}_{21} \mathrm{H}_{40} \mathrm{O}_{2} \mathrm{Si}$ & 352 & 67.00 & $0-00-0$ & Linoleic acid \\
22 & 33.875 & $\mathrm{C}_{21} \mathrm{H}_{42} \mathrm{O}_{2} \mathrm{Si}$ & 254 & 116.95 & $0-00-0$ & 11 -trans-Octadecenoic \\
& & & & & & acid \\
23 & 33.875 & $\mathrm{C}_{21} \mathrm{H}_{42} \mathrm{O}_{2} \mathrm{Si}$ & 354 & 116.95 & $0-00-0$ & cis-13-Octadecenoic acid \\
24 & 33.875 & $\mathrm{C}_{21} \mathrm{H}_{42} \mathrm{O}_{2} \mathrm{Si}$ & 354 & 116.95 & $21556-26-3$ & Oleic acid \\
25 & 34.05 & $\mathrm{C}_{21} \mathrm{H}_{44} \mathrm{O}_{2} \mathrm{Si}$ & 356 & 116.95 & $18748-91-9$ & Hexadecanoic acid \\
26 & 34.05 & $\mathrm{C}_{27} \mathrm{H}_{56} \mathrm{O}_{2} \mathrm{Si}$ & 440 & 116.95 & $74367-37-6$ & Tetracosanoic acid \\
27 & 34.045 & $\mathrm{C}_{18} \mathrm{H}_{38} \mathrm{O}_{2} \mathrm{Si}$ & 314 & 116.45 & $74367-22-9$ & n-Pentadecanoic acid \\
29 & 34.045 & $\mathrm{C}_{22} \mathrm{H}_{46} \mathrm{O}_{2} \mathrm{Si}$ & 370 & 116.95 & $74367-35-4$ & Nonadecanoic acid \\
30 & 34.045 & $\mathrm{C}_{17} \mathrm{H}_{36} \mathrm{O}_{2} \mathrm{Si}$ & 300 & 116.95 & $18603-17-3$ & Tetradecanoic acid \\
& 36.790 & $\mathrm{C}_{16} \mathrm{H}_{22} \mathrm{O}_{4}$ & 278 & 148.90 & $4376-20-9$ & Phtalic acid, \\
& & & & & & mono-(2-ethylhexyl) \\
& & & & & & ester \\
\hline
\end{tabular}

*The nearest library standards.

The match quality in all cases was upper $80 \%$ of coincidence. The first 23 chemical compounds were discarded because they are related with the Silylation agent and their derivatives. The phytochemical components of bark are related in general, with carboxylic acids (saturated and unsaturated), N-compounds, reductants sugars (especially sugar-alcohols) and aromatic compounds, suggesting the great coincidence with the reported data from Gómez after phytochemical screening done using the proposed methodology by Chhabra et al. (1989).

None triterpenes and/or steroids, tannins and/or phenolic compounds and quinones presence was matched with the NIST21 database perhaps MS information of silylated natural products is insufficiently represented in available compound libraries for GC-MS platforms based on electron ionization (EI). More suitable chromatographic profiling platforms such as LC-MS are available for analysis of metabolites with higher polarity and molecular weights up to 2000 Da (Halket et al., 2005).

In order to cope with the tremendous variability of primary but also secondary metabolites detectable by GC-MS, several attempts have been made to facilitate identification through the construction of combined RI and MS databases of derivatized compounds, generally termed 
as mass spectral tags (MST) (Kopka, 2006). Retention time indices are a prerequisite for tentative metabolite annotation of mass spectra showing high similarity such as pentoses and hexoses. Recent efforts have focused on the need for extended and comprehensive RI information by compiling RI values of TMS analytes of various phytochemicals including phenolic acids and flavonoids (Isidorov \& Szczepaniak, 2009; Gao et al., 2010; Esche et al., 2012; Isidorov et al., 2005; Isidorov \& Vinogorova, 2003), diterpenes (Popova et al., 2010), sterols (Esche et al., 2012) and tocopherols (Lytovchenko et al., 2009).

Moreover, several research groups and consortia have addressed the complexity of compound structures, since commercially available libraries (e.g., NIST or Wiley) contained insufficient MS information about derivatized analytes, which are frequently acquired in metabolomics experiments. The Golm Metabolome Database GMD comprise today online information of about $>4600$ MS analyte entries including $>3500$ analytes with valid spectra (TMS derivatives, tributylsilyl (TBS) derivatives, and isotopically-labeled compounds). However more than 1400 spectra have not been annotated underscoring the need for further chemical information in order to approach the metabolome of plants and other organisms (Schauer et al., 2005).

\section{Conclusions}

Despite limitations in GC-MS with respect to the mass range and polarity of metabolites, the utilization of derivatization techniques and automation technology have extended the range of separable and detectable compounds in high-throughput profiling experiments. Beside the qualitative and quantitative analysis of trimethylsilyl derivatives of highly abundant compounds found in plant samples such as sugars, amino acids and polyols, instrument sensitivity and resolution also allows for the successful detection of minor constituents such as plant secondary metabolites. Even though mass spectral information about monophenolic, polyphenolic and other cyclic compounds in MS libraries is limited, structure-specific MS fragmentation patterns enable to trace and identify low-concentration metabolites, often based on and in combination with published MS data from targeted GC-MS analyses.

The spectral analysis of the ethanolic extract showed the majority of thirty-one active compounds among them, 18 monoaromatic or carboxylic acids, 8 reductants sugars and 5 $\mathrm{N}$-compounds. For the first time, at least tentatively, the fingerprint chemical profile of ethanolic extract from the bark of T. elatum (Sw.) can be known based on experimental data from own research. The present result has emphasized the capabilities of GC-MS to deduce chemical information on chemical compounds found in complex mixtures of plant metabolites.

\section{Acknowledgments}

The authors greatly acknowledge technical support to MSc. Delma Calvo González, MEDSOL Laboratories, Havana, Cuba, for her contribution to providing the necessary facilities for carrying out the HPLC profile of the sample.

\section{Conflicts of Interest}

The author(s) confirm that this article content has no conflict of interest.

\section{References}

Adams, R. P. (2007). Identification of Essential Oil Components by Gas 
Chromatography/Mass Spectrometry, 4th ed.; Allured: Carol Stream, IL, USA; p. 804.

Areces F y Fryxell PA. (2007). Flora de la República de Cuba. Fascículo 13. Malvaceae. p. $5-6$.

Chhabra, Sc., Uiso F. C., \& Mshin E. N. (1989). Phytochemical screening of Tanzanian medical plants. I. Journal of Ethnopharmacology, 11, 157-179. https://doi.org/10.1016/0378-8741(84)90037-0

Esche, R., Barnsteiner, A., Scholz, B., \& Engel, K. H. (2012). Simultaneous analysis of free phytosterols/phytostanols and intact phytosteryl/phytostanyl fatty acid and phenolic acid esters in cereals. J. Agric. Food Chem., 60, 5330-5339. https://doi.org/10.1021/jf300878h

Gao, X., Williams, S. J., Woodman, O. L., \& Marriott, P. J. (2010). Comprehensive two-dimensional gas chromatography, retention indices and time-of-flight mass spectra of flavonoids and chalcones. J. Chromatogr. A, 1217, 8317-8326. https://doi.org/10.1016/j.chroma.2010.10.093

Gómez, E. (2017). Tesis de Diploma para optar por el Título de Licenciado en Ciencias Farmacéuticas "Evaluación farmacognóstica preliminar de la corteza de Talipariti elatum Sw. (Fryxell) Malvaceae". La Habana.

González, J., Cuéllar, A., Gómez, E., Dopico, E., Vázquez, R., \& de Armas, T. (2017). Evaluación farmacognóstica y fitoquímica preliminar de los pistilos con polen, la corteza y la madera de Talipariti elatum Sw. Revista de Ciencias Farmacéuticas y Alimentarias, 3(2).

Halket, J. M., Waterman, D., Przyborowska, A. M., Patel, R. K., Fraser, P. D., \& Bramley, P. M. (2005). Chemical derivatization and mass spectral libraries in metabolic profiling by GC/MS and LC/MS/MS. J. Exp. Bot., 56, 219-243. https://doi.org/10.1093/jxb/eri069

Hochmuth, D. (2014). Terpenoids Library: Terpenoids and related constituents of essential oils. Available online: http://massfinder.com/wiki/Terpenoids_Library (accessed on 4 December 2014).

Isidorov, V. A., Kotowska, U., \& Vinogorova, V. T. (2005). GC identification of organic compounds based on partition coefficients of their TMS derivatives in a hexane-acetonitrile system and retention indices. Anal. Sci., 21, 1483-1489. https://doi.org/10.2116/analsci.21.1483

Isidorov, V. A., \& Szczepaniak, L. (2009). Gas chromatographic retention indices of biologically and environmentally important organic compounds on capillary columns with low-polar stationary phases. J. Chromatogr. A, 1216, 8998-9007. https://doi.org/10.1016/j.chroma.2009.10.079

Isidorov, V. A., \& Vinogorova, V. T. (2003). GC-MS analysis of compounds extracted from buds of Populus balsamifera and Populus nigra. Z. Fur Naturforschung C J. Biosci., 58, 355-360. https://doi.org/10.1515/znc-2003-5-612

Kopka, J. (2006). Current challenges and developments in GC-MS based metabolite profiling technology. J. Biotechnol., 124, 312-322. https://doi.org/10.1016/j.jbiotec.2005.12.012

Lytovchenko, A., Beleggia, R., Schauer, N., Isaacson, T., Leuendorf, J. E., Hellmann, H., Rose, J. K., \& Fernie, A. R. (2009). Application of GC-MS for the detection of lipophilic compounds in diverse plant tissues. Plant Methods, 5. https://doi.org/10.1186/1746-4811-5-4 


\section{Macrothink}

Popova, M. P., Graikou, K., Chinou, I., \& Bankova, V. S. (2010). GC-MS profiling of diterpene compounds in Mediterranean propolis from Greece. J. Agric. Food Chem., 58, 3167-3176. https://doi.org/10.1021/jf903841k

Schauer, N., Steinhauser, D., Strelkov, S., Schomburg, D., Allison, G., Moritz, T., Lundgren, K., Roessner-Tunali, U., Forbes, M. G., \& Willmitzer, L. (2005). GC-MS libraries for the rapid identification of metabolites in complex biological samples. FEBS Lett., 579, 1332-1337. https://doi.org/10.1016/j.febslet.2005.01.029

Skogerson, K., Wohlgemuth, G., Barupal, D. K., \& Fiehn, O. (2011). The volatile compound BinBase mass spectral database. BMC Bioinform, 12. https://doi.org/10.1186/1471-2105-12-321

U. S. Department of Agriculture. (2013). Hibiscus elatus Sw. "mahoe". Natural Resources Conservation Service. Plants Database. Retrieved 6 September 2013.

\section{Copyright Disclaimer}

Copyright reserved by the author(s).

This article is an open-access article distributed under the terms and conditions of the Creative Commons Attribution license (http://creativecommons.org/licenses/by/3.0/). 